\title{
Insulin degrading enzyme activity and insulin binding of erythrocytes in normal subjects and Type 2 (non-insulin-dependent) diabetic patients
}

\author{
E. Standl and H.J. Kolb \\ Diabetes Research Unit and Third Medical Department, City Hospital Schwabing, and Institute of Clinical Chemistry, \\ City Hospital Harlaching, Munich, FRG
}

\begin{abstract}
Summary. Specific insulin degrading enzyme activity of erythrocytes was determined in relation to erythrocyte insulin binding in 16 healthy subjects, 14 Type 1 (insulin-dependent) and various groups of Type 2 (non-insulin-dependent) diabetic patients $(n=39)$. Degrading activity was increased in Type 2 diabetic patients on sulphonylureas, as well as in a subgroup with good metabolic control $(p<0.001)$ and in patients with secondary failure to oral therapy $(p<0.02)$; degrading activity returned to normal in the latter patients after 1 week of insulin treatment. Highest degrading activity was found in insulintreated, yet insulin-insensitive patients (daily insulin dose $>80 \mathrm{U})$. Degrading activity was significantly correlated in
\end{abstract}

healthy subjects both with circulating insulin concentrations and maximal specific insulin binding. In contrast, in Type 2 diabetic subjects, degrading activity was inversely correlated with serum insulin with no apparent association with maximal specific insulin binding except in those patients given 1 week of insulin treatment. High erythrocyte insulin degrading enzyme activity might be a common feature in the insulin-insensitive Type 2 diabetic patient and might occur subsequent to some aspect of insulin deficiency at the tissue level.

Key words: Insulin degrading enzyme activity, insulin binding, insulin resistance, Type 2 diabetes, erythrocytes.
The mechanism and physiological significance of insulin inactivation and degradation is still incompletely understood. A cytosolic soluble enzyme which rapidly degrades insulin by proteolysis has been found in many animal [1-12] and some human tissues [12-20]; reductive disulphide cleavage of insulin, i. e. a glutathione-insulin-transhydrogenase activity, has also been described [11, 20-22]. Evidence has accumulated that both insulin action and degradation might be mediated through binding of insulin to specific receptors on the plasma cell membrane as the initial step [12, 13, 18, 19, 23, 24], although the precise nature of this relationship remains to be elucidated. In streptozotocin-diabetic rats, increased insulin degradation by intact muscle has been observed which could be restored to near-normal by insulin treatment [25]. Furthermore, studies in some rare cases of diabetic patients with excessive insulin resistance have suggested that accelerated insulin degradation at the level of target tissues might be a possible alternate explanation for their severe insulin-resistant state [26-31].

The present study was designed to investigate aspects of insulin degradation in human diabetes more generally, assaying a specific insulin degrading protease activity from human erythrocytes which has been puri- fied recently to homogeneity $[14,15]$ and shown to exhibit similar properties as a purified enzyme from human skeletal muscle [20]. Type 2 diabetic patients are of particular interest, in whom peripheral insulin resistance due to a combined receptor and post-receptor defect has been implicated in recent years as one pathogenic factor [32-37]. Insulin degrading enzyme activity (IDEA) and insulin binding to red blood cells in relation to circulating free insulin concentrations were determined in various groups of Type 2 diabetic patients, including some on sulphonylureas, after short-term insulin treatment, and with severe insulin resistance, and compared with normal subjects and with Type 1 diabetic patients.

\section{Subjects and methods}

\section{Subjects}

Six groups of subjects were studied (Table 1 ): 16 healthy control subjects (group 1), 14 well regulated Type 1 diabetic patients (group 2), 13 well controlled Type 2 diabetic patients on sulphonylurea therapy (who required sulphonylureas in addition to adequate diet for good metabolic control, group 3 ), nine poorly controlled Type 2 diabetic patients, with secondary failure to diet and sulphonylureas (group 4), 
Table 1. Clinical characteristics of the patient groups studied

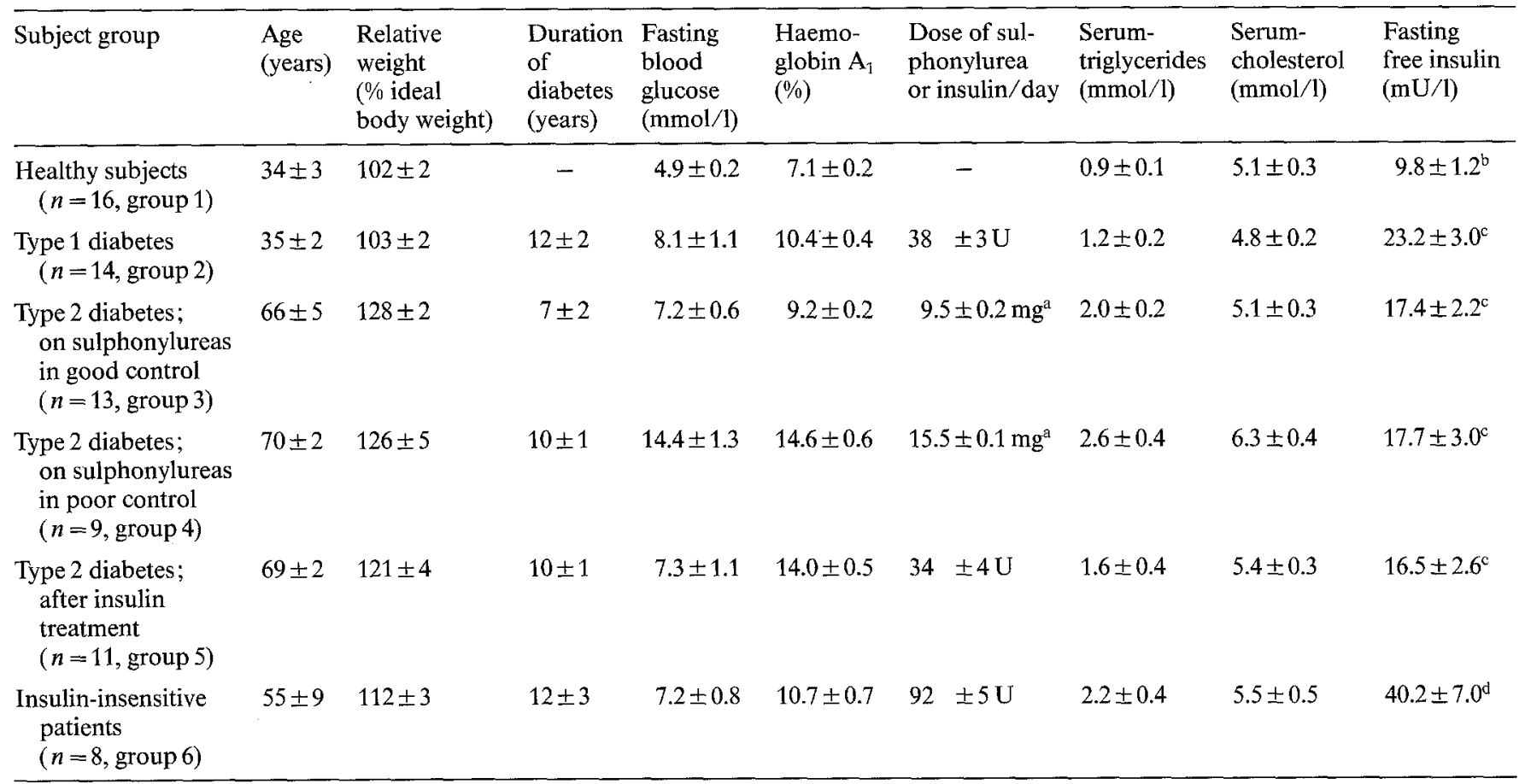

Values are given as mean \pm SEM. a $\mathrm{mg}$ glibenclamide or equivalent dose of gliquidone or glibornuride; ${ }^{\mathrm{b}} p<0.02$ versus all other groups, ${ }^{c} p<0.025$ versus groups 1 and $6,{ }^{\mathrm{d}} p<0.025$ versus all other groups

11 well controlled Type 2 diabetic patients after 1 week of insulin treatment (most of whom were recruited from the nine Type 2 diabetics previously poorly controlled on sulphonylureas in group 4 , group 5) and eight (six Type 2, two Type 1) well-controlled patients on insulin, although insensitive to subcutaneously injected insulin as indicated by a daily need of $>80 \mathrm{U}$, proven in hospital for at least one week (group 6). In this latter group, patients were only included who did not have significant amounts of circulating antibodies, as measured by the method of Dixon [38].

None (including the control subjects) showed evidence of significant hepatic, renal or infectious disease. Except for mild cardiac insufficiency or hypertension, no other medication was taken by any of the subjects. All subjects had a normal blood count, including normal reticulocyte levels. Informed consent was obtained from all subjects participating in the study and approval was given by the local Ethical Committee.

\section{Methods}

All subjects were studied in the morning at $8.00 \mathrm{~h}$ after an overnight fast. Venous blood was drawn from an antecubital vein into heparinized syringes and processed immediately for estimation of IDEA and insulin binding to erythrocytes. Blood, without anticoagulant, was collected for the determination of total and free serum insulin concentrations $[39,40]$ and routine chemical profiles, including serum total cholesterol and triglycerides, using a Technicon SMA II autoanalyzer (Technicon, Dublin, Ireland). Capillary blood was taken for glucose determination by the glucose oxidase method and a Beckman glucose analyzer (Beckman Instruments, Clinical Instruments Division, Fullerton, California, USA). Haemoglobin $A_{1}$ concentrations were estimated using pre-packed microcolumns (Boehringer Mannheim, Mannheim, FRG); the normal range of that method being $6.0 \%-8.5 \%$ in our laboratory.

IDEA of erythrocytes was measured by a standard procedure as described previously $[1-9,12-15,20]$, using a quenching technique with $5 \%$ trichloroacetic acid $[14,15]$. The incubation mixture $(2 \mathrm{ml})$ contained Tris $/ \mathrm{HCl}$ buffer $(10 \mathrm{mmol} / 1, \mathrm{pH} 7.4)$, human albumin
$(1 \mathrm{mg} / \mathrm{ml})$, highly purified pork insulin $(100 \mathrm{mU} / 1$, Nordisk, Copenhagen, Denmark), iodoacetamide $(1 \mathrm{mmol} / \mathrm{l}),{ }^{125} \mathrm{I}$-insulin as tracer $\left(\mathrm{A}_{14^{-}}{ }^{125} \mathrm{I}\right.$-pork insulin, Novo, Copenhagen, Denmark; spec. act. $211-295 \mathrm{Ci} / \mathrm{g}$ ), and $0.5 \mathrm{ml}$ haemolysate of erythrocytes washed three times with normal saline and lysed by adding 10 volumes of distilled water. The mixture was incubated in a shaking water bath at $37^{\circ} \mathrm{C}$ for $25 \mathrm{~min} ; 200 \mu \mathrm{l}$ aliquots were removed at $0,5,15$, and $25 \mathrm{~min}$ and equal amounts of trichloroacetic acid added. After centrifugation at $10,000 \mathrm{~g}$, duplicate aliquots of the supernatant were counted using a gammacounter (Model NE 1600, Nuclear Enterprises, Edinburgh, UK). The concentration of degraded insulin was calculated from the percentage of radioactivity in the trichloroacetic acid soluble fraction. The time turnover curve was linear over the whole period of measurement and, therefore, initial rates of degrading activity were obtained. Figure 1 shows a typical example. To calculate specific activity, an aliquot of the haemolysate was assayed for the haemoglobin concentration. One unit IDEA was defined as $1 \mu \mathrm{U}$ insulin degraded $/ \mathrm{min}$ and related to the concentration of haemoglobin of the haemolysate.

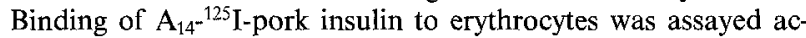
cording to Gambhir et al. $[41,42]$. Incubation time was $5 \mathrm{~h}$ at $15^{\circ} \mathrm{C}$. Concentration of ${ }^{125} \mathrm{I}$-insulin in the incubation medium was $4 \mathrm{mU} / 1$. Non-specific binding was measured in the presence of $2.5 \times 10^{6} \mathrm{mU} / 1$ unlabelled pork insulin. The number of binding sites of erythrocytes $\left(\mathrm{R}_{0}\right.$-value) was obtained from Scatchard analysis of the insulin binding data [43, 44], using the amount of the insulin bound (B) and total insulin concentration minus $B$ as the free insulin concentration $(F)$.

Results are given as mean \pm SEM. All calculations were performed using a programmable calculator (Compucorp 300, Computer Design Corporation, Los Angeles, California, USA) and the standard statistics package for linear regressions, correlation coefficients and two-tailed Student's t-test.

\section{Results}

IDEA of erythrocytes was increased, in comparison with healthy control subjects (group 1), in both groups 


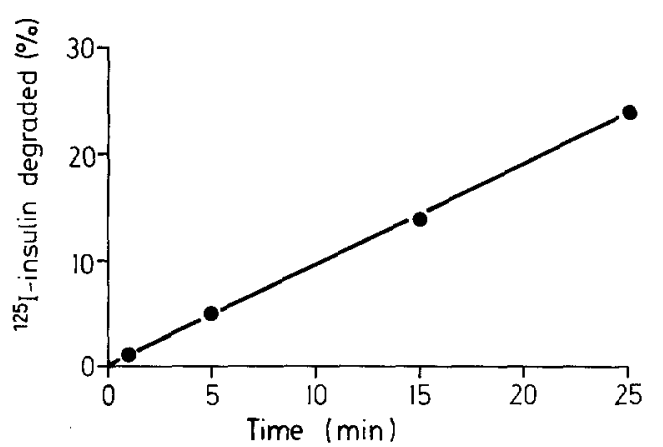

Fig. 1. Example of the determination of IDEA in erythrocytes (see Methods for details of the incubation medium)

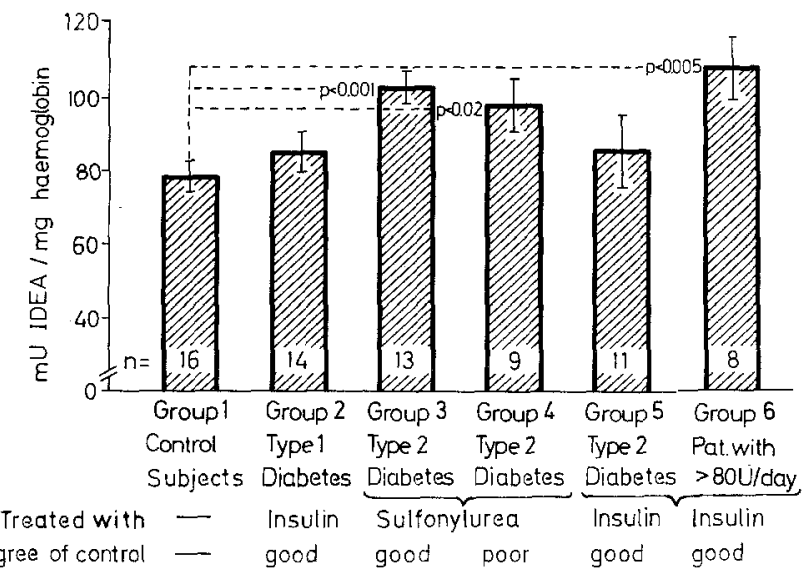

Fig. 2. IDEA of erythrocytes in healthy control subjects and groups of diabetic patients (mean \pm SEM; $1 \mathrm{U}$ IDEA is defined as $1 \mu \mathrm{U}$ insulin degraded $/ \mathrm{min}$ )

of Type 2 diabetic patients on sulphonylureas, as well as in those with good control (group 3) and poor control with secondary failure to diet and oral agents (group 4) (Fig.2). In contrast, after 1 week of insulin treatment resulting in good metabolic control, IDEA became normal in Type 2 diabetic patients, previously poorly controlled on sulphonylureas (group 5), and IDEA was normal in Type 1 diabetic subjects in good metabolic control (group 2). Insulin-treated, yet insulin-insensitive, diabetic patients exhibited the highest IDEA (group 6).

Fasting serum concentrations of free insulin were increased in all groups of diabetic subjects (Table 1), the highest concentrations being found in the insulin-insensitive patients (group 6). The other three groups of Type 2 diabetic patients (groups 3-5) showed remarkably similar fasting insulin levels, including the group with secondary failure to oral therapy (group 4) and the well compensated patients recently changed to insulin treatment (group 5).

Competition curves of insulin binding to erythrocytes are presented in Figure 3A. Maximal specific insulin binding of the poorly controlled Type 2 diabetic patients on sulphonylureas was significantly lower compared with normal subjects $(p<0.01)$, with well regu-
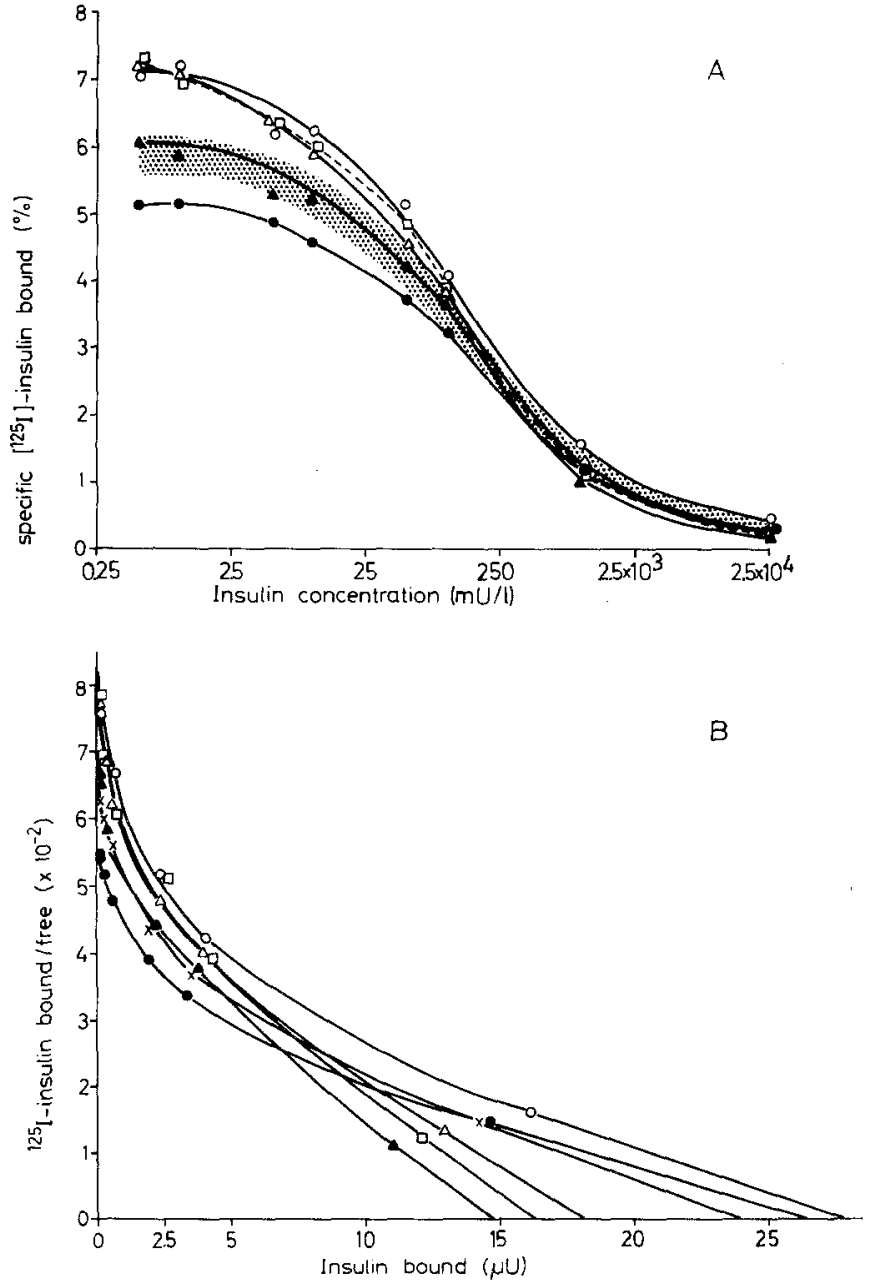

Fig. 3. A and B Insulin binding to erythrocytes in healthy control subjects and groups of diabetic patients. A Competition curves. B Scatchard plots. $x=$ control subjects $(\%=$ mean \pm SEM); $\square=$ Type 1 diabetic patients; $O=$ Type 2 diabetic patients in good control treated with sulphonylureas; $=$ Type 2 diabetic patients in secondary failure to sulphonylurea treatment; $\Delta=$ Type 2 diabetic patients after 1 week of insulin treatment; $\Delta=$ Insulin-insensitive patients with a daily need of insulin $>80 \mathrm{U} /$ day

lated Type 2 diabetic patients either on sulphonylureas $(p<0.01)$ or after insulin treatment $(p<0.01)$, and with the Type 1 diabetic subjects $(p<0.01)$.

Figure $3 \mathrm{~B}$ depicts Scatchard plots of insulin binding to erythrocytes in all groups. Both patient groups on sulphonylureas (groups 3 and 4) showed fairly normal $\mathrm{R}_{0}$-values, i. e. number of receptor sites - despite fasting hyperinsulinaemia. In the insulin-treated groups (groups 2, 5, 6), the number of receptor sites was reduced in an inverse relation to the degree of fasting hyperinsulinaemia.

Significant correlations between maximal specific insulin binding and IDEA of erythrocytes were found in normal subjects $(y=5.49 \mathrm{x}+44.88 ; r=0.59 ; p<0.05)$ and in Type 2 diabetic patients on insulin (group 5; $y=13.80 x-11.18 ; r=0.79 ; p<0.01)$, but not in the sulphonylurea-treated patients (groups 3 and 4 ) or in the insulin-resistant patients (group 6). Furthermore, signif- 


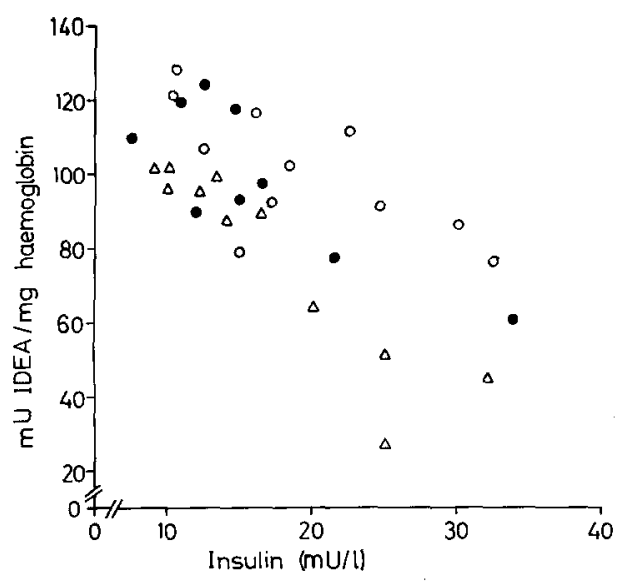

Fig.4. Association of IDEA with fasting serum insulin concentration in groups of Type 2 diabetic patients. $\mathrm{O}=$ in good control treated with sulphonylureas, $\mathbf{O}=$ in secondary failure to sulphonylureas, $\Delta=$ in good control after 1 week of insulin treatment. Regression equation for the whole group: $y=-1.68 \mathrm{x}+124.46 ; r=-0.54, p<0.01$

icant correlations were also found in the normal subjects between insulin concentrations and IDEA $(y=1.86 \mathrm{x}+62.82 ; r=0.61 ; p<0.05)$ and in the Type 1 diabetic patients $(y=1.00 \mathrm{x}+63.42 ; r=0.61 ; p<0.05)$. In contrast, in the Type 2 diabetic patients, significant inverse associations between fasting insulin concentrations and IDEA were apparent (Fig.4), especially in group 4 who had secondary failure to sulphonylurea treatment $(y=-1.72 x+126.54 ; r=-0.72 ; p<0.05)$ and in group 5 who had 1 week of insulin treatment $(y=-3.36 \mathrm{x}+135.96 ; r=-0.84 ; p<0.01)$, i. e. the lower the serum insulin, the higher the IDEA and vice versa.

\section{Discussion}

Although increased insulin degradation has been recognized for many years as a theoretical cause of an impaired response to insulin, only recently have a few diabetic patients been described with extreme resistance to subcutaneous insulin and markedly elevated insulin degrading activity of adipose or muscle tissue [26-31]. The present study now demonstrates more generally elevated and fluctuating IDEA of erythrocytes in a variety of subgroups of patients with Type 2 diabetes.

IDEA, purified to homogeneity, has been characterized recently as a sulphydryl-dependent protease, which specifically degrades insulin at physiological hormone concentrations into peptides smaller than the A-chain of insulin and can be inhibited by several protease inhibitors $[14,15]$. Though red blood cells are not a known target tissue of insulin action, they do carry insulin receptors, and erythrocyte IDEA appears to show properties similar to the insulin degrading proteases of insulinsensitive tissues from animal sources $[1-5,10]$ and especially similar to the enzyme purified from human skeletal muscle [20].

Erythrocyte IDEA as measured here does not contain glutathione-induced-transhydrogenase activity, nor is it affected by free sulphydryl compounds present in the haemolysate, since $1 \mathrm{mmol} / 1$ iodoacetamide was added to the assay mixture [14]. In addition, a sex- or age-dependency of human erythrocyte IDEA has been excluded by measurements in 169 normal subjects [45]. In the context of the trichloroacetic acid method used for the determination of IDEA, it should also be pointed out that the split products of ${ }^{125}$ I-insulin, as found by Sephadex chromatography, have been shown previously to be trichloroacetic-acid soluble and the conversion of ${ }^{125} \mathrm{I}$-insulin to these products to be complete [14-15]. Even if it cannot be ruled out that the trichloroacetic acid method underestimates the degradation of insulin in that the initial split material might be indistinguishable from insulin when Sephadex chromatography is applied [20], this should not interfere with the outcome of the present study since actual rates of increasing trichloroacetic acid soluble products have been determined for the estimation of IDEA.

The present data showed normal IDEA in reasonably well controlled Type 1 diabetic patients (Fig. 2). In contrast, well controlled Type 2 diabetic patients on diet and sulphonylureas showed increased IDEA, as did the Type 2 diabetics with secondary failure to diet and oral agents. Treatment of such patients with insulin for 1 week and thus achieving good metabolic control, resulted in IDEA becoming normal. Erythrocyte IDEA was highest, however, in patients with obvious insensitivity to subcutaneously injected insulin, as indicated by a daily insulin dose of more than $80 \mathrm{U}$, whose insulin resistance could not be attributed to increased circulating insulin antibodies. Furthermore, the present study has accumulated some indirect correlative evidence for a connection between red blood cell IDEA and both fasting insulin concentrations and maximal specific insulin binding to the erythrocyte receptor, particularly in normal subjects. In the Type 2 diabetic patients, however, the correlation of serum insulin levels with IDEA was not direct, but inverse (Fig. 4). These observations appear to agree with findings in the literature, where increased insulin degradation has been described in muscle from insulin-deficient, streptozotocin-diabetic rats, while insulin binding to muscle was increased at the same time, a phenomenon which reverted to normal after one week of insulin treatment [25]. An association of basal plasma insulin values with insulin degrading activities of muscle and fat tissue has also been shown in a previous study in some non-diabetic and diabetic insulin-resistant subjects [27]. These data have been interpreted as suggesting that insulin degrading enzymes are inducible and thereby influencing insulin metabolism or action respectively, with increased insulin degradation going along with a state of both insulin deficiency and insulin resistance $[20,25,27]$. 
Erythrocyte IDEA as reported here is an in vitro phenomenon and may not necessarily reflect the condition in vivo, particularly in insulin target tissues. However, the results seem to warrant subsequent work to substantiate whether increased insulin degradation by insulin-sensitive tissues in vivo is indeed a common feature of Type 2 diabetes and might be involved in the process of peripheral insulin resistance in such patients. This might be of particular importance in view of the now widely accepted notion of post-receptor defects being the predominant origin of insulin resistance in Type 2 diabetes, and not receptor abnormalities [32-37], and that intensive insulin treatment seems to be able to ameliorate considerably post-receptor defects, e.g. in insulin-stimulated glucose disposal [35]. It is of great interest that recent evidence has been obtained that the plasma clearance rate of insulin may vary in diabetes [46-48], with insulin treatment for 1 week returning increased clearance to normal [46], and that there seems to be a close association between insulin clearance, insulin binding and insulin sensitivity $[47,48]$.

Acknowledgements. The excellent technical assistance of Miss V. Schott and Mr. R. Standl is gratefully acknowledged. This work was supported in part by the Deutsche Forschungsgemeinschaft.

\section{References}

1. Brush JS, Kitabchi AE (1970) Metabolic disposition of ${ }^{131}$ I-iodoinsulin within the rat diaphragm. Biochem Biophys Acta 215: 134-144

2. Brush JS (1971) Purification and characterization of a protease with specificity for insulin from rat muscle. Diabetes 20: 140-145

3. Burghen GA, Kitabchi AE, Brush JS (1972) Purification and properties of a rat liver protease with specificity for insulin. Endocrinology 91: 633-642

4. Brush JS, Nascimento CG (1982) Studies on the properties of the insulin protease of rat liver. Biochem Biophys Acta 704: 398-402

5. Duckworth WC, Heinemann M, Kitabchi AE (1972) Purification of insulin specific protease by affinity chromatography. Proc Natl Acad Sci USA 69: 3698-3702

6. Kitabchi AE, Stentz FB (1972) Degradation of insulin and proinsulin by various organ homogenates of rat. Diabetes 21: $1091-1101$

7. Duckworth WC, Kitabchi AE (1974) Insulin and glucagon degradation by the same enzyme. Diabetes $23: 536-543$

8. Funcke HJ, Kolb HJ, Standl E (1975) Rate of insulin degradation in different organs of diabetic rodents. Diabetologia 11:382 (Abstract)

9. Runyan K, Duckworth WC, Kitabchi AE, Huff G (1979) The effect of age on insulin degrading activity in rat tissue. Diabetes 28 : 324-325

10. Yokono K, Imamura Y, Shii K, Sakai H, Baba S (1981) Purification and characterisation of insulin-degrading enzyme from pig skeletal muscle. Endocrinology 108: 1527-1532

11. Poole GP, O'Connor KJO, Lazarus NR, Pogson CI (1982) ${ }^{125} \mathrm{I}-\mathrm{la}-$ belled insulin degradation by isolated rat hepatocytes: the roles of glutathione-insulin transhydrogenase and insulin specific protease. Diabetologia 23: 49-53

12. Beck-Nielsen H, Pedersen O (1979) Insulin binding, insulin degradation and glucose metabolism in human monocytes. Diabetologia 17:77-84

13. Powers AC, Solomon SS, Duckworth WC (1980) Insulin degradation by mononuclear cells. Diabetes $29: 27-32$
14. Kolb HJ, Standl E (1980) Purification to homogeneity of an insulin degrading enzyme from human erythrocytes. Hoppe-Seyler's $Z$ Physiol Chem 361: 1029-1039

15. Kolb HJ, Standl E (1980) An insulin-degrading enzyme from human erythrocytes: isolation and characterisation. In: Brandenburg D, Wollmer A (eds) Insulin - chemistry, structure and function of insulin and related hormones. Walter de Gruyter, Berlin New York, pp 501-508

16. Misbin RI, Davies JG, Afford RE, Halban PA, Mehl TO (1980) Binding and degradation of semisynthetic tritiated insulin by I M cultured human lymphocytes. Diabetes 29:730-735

17. Lang N, Kahn CR, Chrambach A (1980) Characterization of the insulin receptor and insulin-degrading activity from human lymphocytes by quantitative polyacrylamide gel electrophoresis. Endocrinology 106: 40-49

18. Pedersen O, Hjøllund E, Beck-Nielsen H, Lindskov HO, Sonne O, Gliemann J (1981) Insulin receptor binding and receptor-mediated insulin degradation in human adipocytes. Diabetologia 20: 636-641

19. Bellomo G, Bellazzi R, Nicotera PL, Francesconi R, Fratino $P$ (1982) Binding and degradation of ${ }^{125}$ I-insulin in human erythrocytes. Comparative studies with hemolysate and membranes. J Endocrinol Invest 5: 287-291

20. Neal GW, Kitabchi AE (1982) Insulin degradation by human skeletal muscle. Biochem Biophys Acta 719: 259-266

21. Varandani PT (1972) Insulin degradation. I. Purification and properties of glutathione-insulin transhydrogenase of rat liver. Biochem Biophys Acta 286: 126-135

22. Ansorge S, Bohley P, Kirschke H, Wieranders B, Hanson H (1973) Metabolism of insulin and glucagon. Glutathione-insulin transhydrogenase from microsomes of rat liver. Eur J Biochem 32: 27-35

23. Terris S, Steiner DF (1975) Binding and degradation of ${ }^{125}$ I-insulin by rat hepatocytes. J Biol Chem 250:8389-8398

24. Gliemann J, Sonne O (1978) Binding and receptor mediated degradation of insulin in adipocytes. J Biol Chem 253:7857-7863

25. Duckworth WC, Gifford D, Kitabchi AE, Runyan K, Solomon SS (1979) Insulin binding and degradation by muscles from streptozotocin-diabetic rats. Diabetes 28: 746-748

26. Paulsen EP, Courtney JW, Duckworth WC (1979) Insulin resistance caused by massive degradation of subcutaneous insulin. Diabetes 28: 640-645

27. Kitabchi AE, Stentz FB, Cole C, Duckworth WC (1979) Accelerated insulin degradation: an alternate mechanism for insulin resistance. Diabetes Care 2: 414-417

28. Müller WA, Taillers C, Léreret S, Berger M, Philippe J, Halban PA, Offord RE (1980) Resistance against subcutaneous insulin successfully managed with aprotinin. Lancet $1: 1245-1246$

29. McElduff A, Eastman CJ, Haynes SP, Bowen KM (1980) Apparent insulin resistance due to abnormal enzymatic insulin degradation: a new mechanism for insulin resistance. Aust NZ J Med 10: $56-61$

30. Misbin RI, Almira EC, Cleman MW (1981) Insulin degradation in the serum of a patient with apparent insulin resistance. J Clin Endocrinol Metab 52: 117-180

31. Maberly GF, Wait GA, Kilpatrick JA, Loten EG, Gain KR, Stewart RDH, Eastman CJ (1982) Evidence for insulin degradation by muscle and fat tissue in an insulin resistant diabetic patient. Diabetologia 23: 333-336

32. Reaven GM, Bernstein R, Davis B, Olefsky JM (1976) Non-ketotic diabetes mellitus: insulin deficiency or insulin resistance? Am J Med 60: 80-88

33. Koltermann OG, Gray RS, Griffin J, Burnstein P, Insel J, Scarlett JA, OlefskyJM (1981) Receptor and post-receptor defects contribute to the insulin resistance in non-insulin dependent diabetes mellitus. J Clin Invest 68: 957-969

34. Skyler JS (1982) Type II Diabetes: toward improved understanding and rational therapy. Diabetes Care 5: 447-450

35. Scarlett JA, Gray RS, Griffin J, Olefsky JM，Koltermann OG (1982) Insulin treatment reverses the insulin resistance of type II diabetes mellitus. Diabetes Care 5: 353-363

36. Reaven GM, Doberne L, Greenfield MS (1982) Comparison of in- 
sulin secretion and in vivo insulin action in non-obese and moderately obese individuals with non-insulin-dependent diabetes mellitus. Diabetes 31: 382-384

37. Bolinder J, Östman J, Arner P (1982) Postreceptor defects causing insulin resistance in normoinsulinemic non-insulin-dependent diabetes mellitus. Diabetes 31:911-916

38. Dixon K (1974) Measurement of antibodies to insulin in serum. Clin Chem 20: 1275-1281

39. Nakagawa $S$, Nagayama H, Sasaki T (1973) A simple method for the determination of serum free insulin levels in insulin-treated diabetic patients. Diabetes 22: 590-600

40. Heding LG (1971) Determination of total serum insulin in insulintreated diabetic patients. Diabetologia 8: 260-266

41. Gambhir KK, Archer JA, Canter L (1977) Insulin radioreceptorassay for human erythrocytes. Clin Chem 23:1590-1595

42. Gambhir KK, Archer JA, Bradley CJ (1978) Characteristics of human erythrocyte insulin receptors. Diabetes $27: 701-708$

43. Scatchard G (1949) The attraction of proteins for small molecules and ions. Ann NY Acad Sci 51: 660-672

44. De Meyts P, Roth J (1975) Cooperativity in ligand binding: a new graphic analysis. Biochem Biophys Res Commun 66: 1118-1126

45. Schneider H (1982) Messungen einer spezifischen Insulinaseaktivität in Erythrozyten von Normalpersonen und Diabetikern. Inaugural-Dissertation, University of Munich
46. Philippe J, Halban PA, Gjinovci A, Duckworth WC, Estreicher J, Renold AE (1981) Increased clearance and degradation of $\left({ }^{3} \mathrm{H}\right)$ insulin in streptozotocin diabetic rats. Role of the insulin receptor compartment. J Clin Invest 67: 673-680

47. Nosadini R, Del Prato S, Tiengo A, Duner E, Toffolo G, Cobelli C, Faronato PP, Moghetti P, Muggeo M (1982) Insulin sensitivity, binding, and kinetics in pancreatogenic and Type I diabetes. Diabetes $31: 346-355$

48. Flier JS, Minaker KL, Landsberg L, Young JB, Pallotta J, Rowe JW (1982) Impaired in vitro insulin clearance in patients with severe target cell resistance to insulin. Diabetes 31: 132-135

Received: 14 July 1983

and in revised form: 9 May 1984

Professor Dr. E. Standl

Diabetes Research Unit and

Third Medical Department

City Hospital Schwabing

Kölner Platz 1

D-8000 Munich 40

FRG 